\title{
Acetylcholinesterase activity in the pons and medulla oblongata of rats after chronic electroconvulsive shock
}

R. Camarini and M.A.C. Benedito

\author{
Departamento de Psicobiologia, Escola Paulista de Medicina, \\ Universidade Federal de São Paulo, São Paulo, SP, Brasil
}

\begin{abstract}
Correspondence

M.A.C. Benedito

Departamento de Psicobiologia

Escola Paulista de Medicina, UNIFESP

Rua Botucatu, 862, 1ำ andar

04023-060 São Paulo, SP

Brasil

Fax: 55 (011) 572-5092

Research supported by FAPESP and Associação Fundo de Incentivo à

Psicofarmacologia (AFIP).

R. Camarini was the recipient of

a FAPESP fellowship.

....................

Received March 10, 1997

Accepted August 18, 1997

...................

An imbalance between cholinergic and noradrenergic neurotransmission has been proposed for the etiology of affective disorders. According to this hypothesis, depression would be the result of enhanced cholinergic and reduced noradrenergic neurotransmission. Repeated electroconvulsive shock (ECS) is an effective treatment for depression; moreover, in laboratory animals it induces changes in brain noradrenergic neurotransmission similar to those obtained by chronic treatment with antidepressant drugs (down-regulation of beta-adrenergic receptors). The aim of the present study was to determine whether repeated ECS in rats changes acetylcholinesterase (Achase) activity. Achase controls the level of acetylcholine (Ach) in the synaptic cleft and its levels seem to be regulated by the interaction between Ach and its receptor. Thus, a decrease in Achase activity would suggest decreased cholinergic activity. Adult male Wistar rats received one ECS $(80 \mathrm{~mA}, 0.2 \mathrm{~s}, 60 \mathrm{~Hz})$ daily for 7 days. Control rats were handled in the same way without receiving the shock. Rats were sacrificed $24 \mathrm{~h}$ after the last ECS and membrane-bound and soluble Achase activity was assayed in homogenates obtained from the pons and medulla oblongata. A statistically significant decrease in membrane-bound Achase activity (nmol thiocholine formed $\mathrm{min}^{-1} \mathrm{mg}$ protein $\left.^{-1}\right)($ control $182.6 \pm 14.8$, ECS $162.2 \pm 14.2, \mathrm{P}<0.05)$ and an increase in soluble Achase activity in the medulla oblongata (control $133.6 \pm 4.2$, ECS $145.8 \pm 12.3, \mathrm{P}<0.05$ ) were observed. No statistical differences were observed in Achase activity in the pons. Although repeated ECS induced a decrease in membrane-bound Achase activity, the lack of changes in the pons (control Achase activity: total 231.0 \pm 34.5 , membrane-bound $298.9 \pm 18.5$, soluble $203.9 \pm 30.9$ ), the region where the locus coeruleus, the main noradrenergic nucleus, is located, does not seem to favor the existence of an interaction between cholinergic and noradrenergic neurotransmission after ECS treatment.
\end{abstract}

Electroconvulsive shock (ECS) is a classical antidepressive treatment (1) and its therapeutical effect is observed after repeated sessions. The time span between the onset of treatment and the improvement in mood seems to be related to adaptive biochemical changes that occur in the brain. In laboratory
Key words

- Acetylcholinesterase

- Medulla oblongata

- Pons

- Chronic electroconvulsive shock animals, repeated ECS treatment induces changes in noradrenergic neurotransmission which are similar to those produced by chronic antidepressant drugs, including down-regulation of beta-adrenergic receptors and reduced synthesis of cyclic adenosine monophosphate (cAMP) induced by 
noradrenergic agonists (for a review, see Ref. 2).

An imbalance between noradrenergic and cholinergic neurotransmission has been proposed for the etiology of affective disorders (for a review, see Ref. 2). According to this hypothesis, depression may be the result of an overactive cholinergic neurotransmission and reduced noradrenergic activity. Antidepressant drugs (inhibitors of noradrenaline uptake and monoamine oxidase activity) along with ECS seem to improve depression by increasing noradrenergic neurotransmission (2). According to the noradrenergiccholinergic interaction hypothesis, these treatments should lead to a decrease in cholinergic neurotransmission.

The brainstem is the brain region where the cell bodies of noradrenergic neurons are located (3). This brain region also has cell bodies of cholinergic neurons anatomically connected to noradrenergic neurons (4) and they interact mutually (5). The locus coeruleus (LC) is the main noradrenergic nucleus in the brainstem and sends projections to several brain areas, including the hippocampus and cerebral cortex (3) according to a spatial distribution within the nucleus (6). The locus coeruleus receives cholinergic inputs from brainstem cholinergic neurons (4) and acetylcholine (Ach) acting on $\mathrm{M}_{2}$-muscarinic receptors increases the firing rate of LC neurons (7). Acetylcholinesterase (Achase), the enzyme that inactivates Ach, is located postsynaptically (8) and has been reported to be present in the membranes of LC neurons (9). Large territories of the brainstem that receive a dense noradrenergic input are very sparsely innervated by LC neurons (10). Repeated ECS increases tyrosine hydroxylase activity and its messenger RNA in LC $(11,12)$. Taken together, these data indicate that the brainstem is an appropriate brain region for the study of a possible interaction between cholinergic and noradrenergic neurotransmission after ECS treatment.

To our knowledge, there is no previous report on the effects of repeated ECS on Achase activity in the pons and medulla oblongata. Appleyard et al. (13) have reported no change in Achase activity in the whole brainstem of female rats after only one convulsion induced by ECS. The aim of the present study was to determine whether repeated ECS treatment in rats induces a decrease in Achase activity. Achase is the enzyme responsible for Ach inactivation and controls the levels of Ach in the synaptic cleft (14). Moreover, the level of the enzyme appears to be controlled by Ach interacting with its receptor (15). Thus, a change in Achase activity could be an indication of altered cholinergic activity.

Adult male Wistar rats (3 months old) received one ECS treatment daily for 7 days $(80 \mathrm{~mA}, 0.2 \mathrm{~s}, 60 \mathrm{~Hz})$ by means of ear-clip electrodes. All ECS-treated rats presented a full tonic-clonic convulsion. Control rats were handled in the same way as the experimental group, except that no shock was delivered. Control and experimental rats were decapitated $24 \mathrm{~h}$ after the last ECS session and the brainstem was dissected and divided into its subregions, pons and medulla oblongata. Homogenates of these brain regions were prepared in cold $0.32 \mathrm{M}$ sucrose and centrifuged in order to obtain membrane-bound and soluble Achase (16). Total (900 $g$ supernatant), membrane-bound $(100,000 \mathrm{~g}$ sediment) and soluble $(100,000 \mathrm{~g}$ supernatant) Achase activity was assayed photometrically using acetylthiocholine as the substrate (1 $\mathrm{mM}$ final concentration in the assay) as described in detail elsewhere (17). The assay was carried out in the linear range for both protein concentration and incubation time. Protein was assayed in the homogenates (18) and the enzyme specific activity is reported as nmol thiocholine formed $\mathrm{min}^{-1} \mathrm{mg}$ protein $^{-1}$.

There was a statistically significant decrease in the activity of membrane-bound Achase in the medulla oblongata $(t=2.26$, d.f. $=8, \mathrm{P}<0.05$, one-tailed unpaired Student 
$t$-test) (Table 1), and an increase in the activity of the soluble enzyme $(\mathrm{t}=2.10$, d.f. $=8$, $\mathrm{P}<0.05$ ) (Table 1). The ECS treatment did not induce any significant alteration in the activity of either enzyme form in the pons (P>0.05) (Table 1).

Achase seems to be mainly located postsynaptically in the brain (8). Most of the Achase present in mammalian brain is the globular G4 form which is virtually membrane-bound and predominantly extracellular (14). This form of the enzyme also predominates in the brainstem (19). In skeletal muscle, the amount of Achase G4 isoform is controlled by an interaction between Ach and the cholinergic receptor (15). Increased frequency of Ach-cholinergic receptor interaction enhances the production of this isoform. Thus, the decrease in Achase bound to membranes in the medulla oblongata might indicate a reduced Ach-cholinergic receptor interaction, which may reflect a decrease in cholinergic activity in this brain region. Since there is no previous indication of any involvement of the medulla oblongata in the antidepressant effect of ECS, the change in Achase activity obtained in this brain region may not be associated with the antidepressant effect of ECS. The lack of change in Achase activity observed in the pons, the brain region where the most important noradrenergic nucleus (LC) is located $(3,6)$, may also indicate that the change in Achase activity observed in the medulla oblongata is not involved in the antidepressant effect of ECS.

We also measured Achase activity in several other brain regions (whole cerebral cortex, frontal cortex, hippocampus, striatum and thalamus) after repeated ECS (data not shown). These brain areas are known to receive cholinergic and noradrenergic inputs $(3,4,6)$. The data obtained in these stud-
Table 1 - Specific activity of Achase in the medulla oblongata and pons of rats after chronic ECS treatment.

Rats received one ECS daily for 7 days and were sacrificed $24 \mathrm{~h}$ after the last ECS. Achase was assayed using acetylthiocholine as the substrate. Data are reported as mean $\pm S D$ ( $N=5$ for all measurements). ${ }^{*} P<0.05$ compared to control (Student $t$-test).

\begin{tabular}{lccc}
\hline Brain region & \multicolumn{3}{c}{$\begin{array}{c}\text { Achase activity } \\
\left.\text { (nmol thiocholine formed } \mathrm{min}^{-1} \mathrm{mg} \mathrm{protein}^{-1}\right)\end{array}$} \\
\cline { 2 - 4 } & $\begin{array}{c}\text { Total } \\
\text { (900 g supernatant) }\end{array}$ & $\begin{array}{c}\text { Membrane-bound } \\
(100,000 \mathrm{~g} \text { sediment) }\end{array}$ & $\begin{array}{c}\text { Soluble } \\
(100,000 \mathrm{~g} \text { supernatant })\end{array}$ \\
\hline Medulla oblongata & & & \\
$\quad$ Control & $152.6 \pm 7.9$ & $182.6 \pm 14.8$ & $133.6 \pm 4.2$ \\
ECS & $158.4 \pm 7.4$ & $162.2 \pm 14.2^{*}$ & $145.8 \pm 12.3^{*}$ \\
Pons & & & \\
Control & $231.0 \pm 34.5$ & $298.9 \pm 18.5$ & $203.9 \pm 30.9$ \\
ECS & $242.4 \pm 39.7$ & $297.9 \pm 34.7$ & $204.3 \pm 32.6$ \\
\end{tabular}

ies showed no statistically significant differences in Achase activity after ECS treatment. These results are consistent with previous data obtained for female rats after 10 ECS (20), with the exception of the striatum where an increase in Achase activity was reported. However, we were not able to demonstrate an increase of Achase activity in the striatum using male rats and 7 ECS sessions and cannot explain the difference between our results and those reported in Ref. 20.

Although we demonstrated a decrease in membrane-bound Achase activity in the medulla oblongata after repeated ECS treatment, the lack of change in enzyme activity in the pons and other brain regions assayed does not favor the hypothesis of a noradrenergic-cholinergic interaction.

\section{Acknowledgments}

We thank Dr. Deborah Suchecki for helping with the preparation of the manuscript and Ms. Ines Monaco for typing the manuscript. 


\section{References}

1. Sackein HA, Devanand DP \& Nobler MS (1995). Electroconvulsive therapy. In: Bloom FE \& Kupfer DJ (Editors), Psychopharmacology: The Fourth Generation of Progress. Raven Press, New York, 11231141.

2. Caldeccot-Hazard S, Morgan DG, De Leon-Jones F, Overstreet DH \& Janowsky D (1996). Clinical and biochemical aspects of depressive disorders: II. Transmitter/ receptor theories. Synapse, 9: 251-301.

3. Moore RY (1982). Catecholamine neuron systems in brain. Annals of Neurology, 12: 321-327.

4. Woolf N (1991). Cholinergic systems in mammalian brain and spinal cord. Progress in Neurobiology, 37: 475-524.

5. Koyama $Y$ \& Kayama $Y$ (1993). Mutual interactions among cholinergic, noradrenergic and serotonergic neurons studied by ionophoresis of these transmitters in rat brainstem nuclei. Neuroscience, 55: 1117-1126.

6. Loughlin SE, Foote SL \& Bloom FE (1986). Efferent projections of nucleus locus coeruleus: topographic organization of cells of origin demonstrated by three-dimensional reconstruction. Neuroscience, 18: 291-306.

7. Egan TM \& North RA (1985). Acetylcholine acts on $\mathrm{M}_{2}$-muscarinic receptor to excite rat locus coeruleus neurons. British Journal of Pharmacology, 85: 733-735.

8. McBride WJ \& Cohen H (1972). Cytochemical localization of acetylcholinesterase on isolated synaptosomes. Brain Research, 41: 489-493.
9. Albanese A \& Butcher LL (1980). Acetylcholinesterase and catecholamine distribution in the locus coeruleus of the rat. Brain Research Bulletin, 5: 127-134.

10. Fritschy JM \& Grzanna R (1990). Distribution of locus coeruleus axons within the rat brainstem demonstrated by Phaseolus vulgaris leucoagglutinin anterograde tracing in combination with dopamine-ßhydroxylase immunofluorescence. Journal of Comparative Neurology, 293: 616631.

11. Masserano JM, Takimoto GS \& Weiner $N$ (1981). Electroconvulsive shock increases tyrosine hydroxylase activity in the brain and adrenal gland of the rat. Science, 214: 662-665.

12. Kapur $S$, Austin MC, Underwood MD, Arango V \& Mann JJ (1993). Electroconvulsive shock increases tyrosine hydroxylase and neuropeptide $\mathrm{Y}$ gene expression in the locus coeruleus. Molecular Brain Research, 18: 121-126.

13. Appleyard ME, Green AR \& Smith $A D$ (1986). Acetylcholinesterase activity in regions of the rat brain following a convulsion. Journal of Neurochemistry, 46: 1789-1793.

14. Brimijoin S (1983). Molecular forms of acetylcholinesterase in brain, nerve and muscle: nature, localization and dynamics. Progress in Neurobiology, 21: 291322.
15. Fernandez HL \& Hodges-Savola CA (1992). Trophic regulation of acetylcholinesterase isoenzymes in adult mammalian skeletal muscles. Neurochemical Research, 17: 115-124.

16. Chubb IW \& Smith AD (1975). Isoenzymes of soluble and membrane-bound acetylcholinesterase in bovine splanchnic nerve and adrenal medulla. Proceedings of the Royal Society of London, Series B, 191: 245-261.

17. Camarini R \& Benedito MAC (1997). Rapid eye movement (REM) sleep deprivation reduces rat frontal cortex acetylcholinesterase (EC 3.1.1.7) activity. Brazilian Journal of Medical and Biological Research, 30: 641-647.

18. Lowry OH, Rosebrough NJ, Farr AL \& Randall RJ (1951). Protein measurement with the Folin phenol reagent. Journal of Biological Chemistry, 193: 265-275.

19. Clark DK \& Lenz DE (1983). Characterization of the molecular forms of acetylcholinesterase in discrete areas of the rat brain. Federation Proceedings, 42: 2024 (Abstract).

20. Appleyard ME \& Green A (1987). Acetylcholinesterase activity in regions of rat brain following repeated administration of electroconvulsive shock. Journal of Psychopharmacology, 1: 211-215. 